\title{
AKIBAT HUKUM PEMBATALAN AKTA PERJANJIAN PENGIKATAN JUAL BELI (PPJB) YANG DiKERJAKAN OLEH DEBITUR TANPA MEMENUHI PRESTASI DALAM PERJANJIAN (STUDI PUTUSAN NOMOR: 571/PDT/2017/PT.BDG)
}

\author{
Sesa Merindah Putri \\ (Mahasiswa Program S1 Fakultas Hukum Universitas Tarumanagara) \\ (E-mail: sesamerindahs@yahoo.com)

\section{Dr. Endang Pandamdari S.H., CN., M.H.} \\ (Corresponding Author)
}

(Dosen Fakultas Hukum Universitas Tarumanagara. Meraih Sarjana Hukum pada Fakultas Hukum Universitas Tarumanegara, Magister Hukum pada Fakultas Hukum Universitas Indonesia)

(E-mail: rasji@fh.untar.ac.id)

\begin{abstract}
The agreement is an event in which a person pledges to another person to know where two people promise to do one thing. to be able to make an agreement then it must fulfill the legal requirements of an agreement set forth in article 1320 of the law of civil law. upon fulfillment of the parties may enter into a sale and purchase agreement where prior to the sale and purchase of the parties entered into a preliminary agreement which is commonly referred to as the sale and purchase agreement. in the execution of the sale and purchase agreement of the parties sometimes does not conform to what is entered into in the agreement, so the agreement can be canceled by the party. the factor is affecting cancellation of deed and sale and purchase agreement are the sale price agreed upon in the agreement not being repaid by the buyer until the agreed period of time.
\end{abstract}

Keywords: cancellation of promises, binding sale and purchase agreement, defaults

\section{PENDAHULUAN}

\section{A. Latar Belakang}


Manusia adalah makhluk sosial yang dalam kegiatan kehidupan sehariharinya, berinterkasi dengan sesamanya. Interaksi yang terjadi antara satu individu dengan individu lainnya, antara individu dengan kelompok lainnya. hal itu dapat dilihat dari adanya suatu perjanjian antara para pihak. Pada perkembangan arus globalisasi ekonomi di bidang jasa sangat berkembang dengan pesat sehingga masyarakat semakin banyak yang mengikatkan dirinya dengan masyarakat lainnya, sehingga timbulnya perjanjian. Dan perjanjian sangat sering dipergunakan dan dibutuhkan dalam masyarakat.

Secara yuridis perjanjian diatur didalam buku ketiga tentang perikatan. Definisi perjanjian menurut Pasal 1313 Kitab Undang-Undang Hukum Perdata (yang selanjutnya disingkat dengan "KUHPerdata") menyebutkan bahwa : "suatu perbuatan dengan mana satu orang atau lebih mengikatkan dirinya terhadap satu orang lain atau lebih". Hukum perjanjian menganut sistem terbuka artinya memberikan kebebasan yang seluas-luasnya kepada masyarakat untuk mengadakan perjanjian yang berisi apa saja, asalkan tidak melanggar ketertiban umum dan kesusilaan sebagaimana yang sudah diatur dalam undang-undang. Sumber perikatan yaitu perikatan yang lahir dari undang-undang maupun perikatan yang lahir dari perjanjian, sumber terpenting dari perikatan adalah perjanjian. Perikatan yang lahir dari perjanjian memang dikehendaki oleh para pihak karena perjanjian tersebut dibuat dan didasarkan atas kesepakatan dan kehendak para pihak, sedangkan perikatan yang berasal dari Undangndang menurut Pasal 1352 KUHPerdata ikatan yang dilahirkan demi undang-undang, tiimbul dari Undang-udang saja, atau dari undang-undang sebagai akibat perkerjaan orang.

Perjanjiani di dalam terkadang ada suatu persyaratan, hal atau kewajiban dari para pihak yang seharusnya memenuhi kewajibannya tetapi tidak memenuhi kewajibannya. Sebagaimana ditentukan dalam Pasal 1320 Kitab Undang-Undang Hukum Perdata (yang selanjutnya disingkat dengan 
"KUHPerdata") menyebutkan untuk sahnya suatu perjanjian diperlukan empat syarat $^{1)}$ :

1. Sepakat mereka yang mengikatkan dirinya;

2. Kecakapan untuk membuat suatu perikatan;

3. Suatu hal tertentu;

4. Suatu sebab yang halal;

Saat dipenuhinya empat syarat perjanjian tersebut, maka suatu perjanjian menjadi sah dan mengikat secara hukum bagi para pihak yang membuatnya. Jika dalam hal syarat obyektif, kalau tidak dipenuhi, perjanjian itu batal demi hukum. Artinya: dari semula tidak pernah dilahirkan suatu perjanjian dan tidak pernah ada suatu perikatan. Tujuan para pihak yang mengadakan perjanjian tersebut untuk melahirkan suatu perikatan hukum, adalah gagal. Dalam hal syarat subyektif, apabila tidak dipenuhi perjanjian bukan batal demi hukum, tetapi salah satu pihak mempunyai hak untuk meminta supaya perjanjian itu dibatalkan. Pihak yang dapat meminta pembatalan adalah pihak yang tidak cakap atau pihak yang memberikan sepakatnya (perizinannya) secara tidak bebas. $^{2)}$

Perjanjian Jual Beli merupakan perjanjian timbal-balik yang menyeret 2 pihak yaitu sipenjual dan sipembeli. Ke-dua belah pihak yang membuatya perjanjian masing-masing punys hak dan kewajiban untuk melaksanakan iisi perjanjian yang dia buat dimana seperti kesepakatan yang telah dipersetujui oleh pihak-pihak. Isi janji itu yaitu dimana salah satu pihak melaksanakan kewajibannya, sedangkan pihak lainnya mengakuinya atau janji untuk memberikan ganti rugi apabila terjadi pelanggaran terhadap isi kontrak. ${ }^{3)}$ Perjanjian jual beli (PJB) menurut Subekti adalah: "Perjanjian antar pihak penjual dan pihak pembeli sebelum dilaksanakannya jual beli dikarenakan

\footnotetext{
1) Pasal 1320 KUH Perdata.

2) Subektii, Hukum Perjanjian, (Jakarta: Intermasa,2005), hal. 20.

3) Salim, teknik pembuatan akta perjanjian, (Jakarta: Rajawali Pers, 2017) hal. 266.
} 
adanya unsur-unsur yang harus dipenuhi untuk jual beli tersebut antara lain adalah sertifikat belum ada karena masih dalam proses, belum terjadinya pelunasan harga". ${ }^{4)}$ Jual beli menurut Pasal 1457 KUHPerdata adalah "suatu perjanjian, dengan mana pihak yang satu mengikatkan dirinya untuk menyerahkan suatu kebendaan, dan pihak yang lain untuk membayar harga yang telah dijanjikan". Para prinsipnya suatu perjanjian pengikatan menjual membeli tanah (yang selanjutnya disingkat dengan "PPJB") tunduk pada ketentuan umum perjanjian yang terdapat dalam Buku III Kitab Undangundang Hukum Perdata tentang perikatan Pasal 1313 KUHPerdata memberian rumusan tentang perjanjian. Pihak yang membuat surat ikatan membeli dan menjual tanah dihadapan notaris. Perikatan dimaksud bagai janji terlebih dahulu dengan tujuan utama agar pihak melakukan pertukaran hak atas tanah. Perjanjian jual beli ini mengandung janji untuk menjual tanah jika syaratnya yang siperlukan telah dipenuhi. ${ }^{5}$ ) Akta pengikatan perjanjian jual beli merupakan surat tanda bukti yang memuat klausula-klausula yang berkaitan dengan perjanjian pengikatan jual beli. ${ }^{6}$

Perjanjian Pengikatan Jual Beli (PPJB) tanah dalam hal ini biasanya masalah yang mungkin timbul adalah ketidakpastian unsur perjanjian dan pembelian antara lain, surat tanah yang masih belum terwujud karena masih didalam prosesnya, masih belum membayar pajak yang dipakai atas penjualan tanah yang belum dibayar oleh para penjual. Perjanjian pengikatan menjual membeli (PPJB) dilahir bagaian akibat terlambatnya /dapatnya sejumlah syarat yang ditentukan oleh undangundang berkaitann dengan jual-beli hak diatas tanah yang akihirnya sedikit menghalangi penyelesaiannya urusniaga dialam jualan beli hak atas tanah. Jalannya suatu perjanjian terkadang tidak sesuai

\footnotetext{
4) R. Subekti, aneka perijanjian, (Bandung: Alumni, 1985), hal. 75.

5) Supriadi, etika dan tanggung jawab profesi hukum di Indonesia, (Jakarta: Sinar Grafika, 2006) hal.12.

6) Salim HS, Teknik Pembuatan Akta Perjanjian (TPA Dua), (Jakarta: RadjaGrafindo, 2017), hal. 266.
} 
dengan apa yang diharapkan, Apabila suatu perjanjian dilanggar atau tidak ditepati seperti apa yang telah disepakati dalan perjanjian maka pihak yang belum memenuhi kewajibannya telah gagal melakukan prestasi.

Abdulkadir Muhammad, dalam bukunya "Hukum Perdata Indonesia", menuliskan bahwa wanprestasi maknanya tidak memenuhi kewajiban yang telah disetujui dalam perikatan. ${ }^{7)}$ Wanprestasi (lalaiannya sama kealpaan) salah satu pihak dalam perjanjian ada empat kategori:

a. Tidak mengerjakan apa yang disanggupi akan dilakukannya;

b. Melaksanakan apa yang dijanjikannya, tetapi tidak seperti yang dijanjikan;

c. Melaksanakan apa yang dijanjikan tetapi tidak tepat waktu;

d. Melasanakan sesuatu yang menurut perjanjian dilarang untuk dilakukan. ${ }^{8)}$

Seperti kasus yang penulis ambil dari Pemutusan Pengadilan Tinggi Bandung Nomor 571/Pdt/2017/PT.BDG. Kasus yang akan penulis angkat adalah bermula dari Perjanjian jual beli tanah yang dilakukan oleh Suhada (selaku penggugat) dengan Jhoni Hendra (selaku tergugat), sebagaimana telah melakukan perjanjian jual beli dengan penjualan tanah yang mengikat no.10 dihadapan Gusti Rahmawati, S.H. selaku notaris di Kota Depok dengan total luas 12.981 $\mathrm{m}^{2}$ yang terletak di Kecamatan Limo Kota Depok seharga Rp8.437.650.000,00 (delapan miliar empat ratus tiga puluh tujuh enam ratus lima puluh ribu rupiah). Mengenai isi akta yang dibikin oleh pihak-pihak, didasarkan atas setuju antara penjual dan pembeli. Perjanjian pengikatan jual beli tersebut dibuat dikarenakan adanya unsur-unsur yang belum dipenuhi oleh tergugat terkait belum dilakukannya pelunasan harga terhadap objek yang diperjanjikan, yang berakhir pada bulan Desember 2016.

Karena tergugat berniat untuk membeli dengan membayar secara dicicil atau bertahap oleh sebab itu, maka dilaksanakan perjanjian pengikatan jual beli

\footnotetext{
7) Abdulkadir Muhammad, Hukum Perdata Indonesia,cetakan ke-5, (Bandung: Citra Aditya Bakti, 2014), hal. 241.

${ }^{8)}$ Subekti, op. cit., hal. 45.
} 
di hadapan notaris. Dimana dalam isi perjanjian tersebut penggugat dan tergugat telah sepakat mengenai termin pembayaran pelunasan harga objek perjanjian beserta denda dan lain-lainnya apabila di kemudian hari memungkinkan akan terjadi wanprestasi, tetapi sampai tanggal yang telah disepakati kedua belah pihak yaitu tanggal 21 Agustus 2016 tergugat baru membayar sebesar Rp. 650.000.000, dimana hal tersebut tidak sesuai dengan termin atau massa pembayaran tanah dalam akta perjanjian pengikatan jual beli tanah tanggal 21 November 2014 yang penggugat dan tergugat sepakati bersama. Dimana tergugat tidak atau belum juga melakukan pembayaran sesuai massa atau waktu yang ditentukan, dan tergugat juga tidak melakukan pembayaran denda yang timbul akibat keterlambatan pembayaran maka tergugat dianggap lalai dan melakukan Wanprestasi dalam perjanjian yang telah disepakati. maka penjual atau penggugat merasa dirugikan, berdasarkan kondisi tersebut penggugat meminta pembatalan atas akta perjanjian pengikatan jual beli (PPJB) No. 10 tanggal 21 November 2014 yang diterbitkan oleh Notaris Gusti Rahmawati, S.H. Berdasarkan latar belakang diatas maka penulis tertarik mengadakan penilitian lebih lanjut tentang hal tersebut kedalam suatu penulisan proposal dengan judul : “Akibat Hukum Pembatalan Akta Perjanjian Pengikatann Jual Beli (PPJB) Yang Dikerjakan Oleh Debitur Tanpa Memenuhi Prestasi Dalam Perjanjian (Studi Putusan Nomor: 571/PDT/2017/PT.BDG)”.

\section{B. Perumusan Masalah}

Berdasarkan penjelasan dari latar belakang diatas, adapun yang menjadi permasalahan dalam penulisan skripsi ini adalah :

1. Bagaimana akibat hukum pembatalan Akta Perjanjian Pengikatan Jual Beli (PPJB) yang dilakukan oleh debitur tanpa memenuhi prestasi dalam perjanjian?

2. Bagaimana pertimbangan undang-undang yang digunakan oleh hakim dalam mengambil keputusan atas batalnya Surat Perikatan Perjanjian Jual Beli 
(PPJB) dalam Putusan Pengadilan Tinggi Jawa Barat No 571/PDT/2017/PT.BDG ?

\section{Metode Penelitian}

Metode merupakan proses, prinsip dan cara untuk memecahkan siuatu masalah, sedangkan penelitian adalah memeriksaan dengann hati-hati, taat dan selesai terhadap suatu tanda untuk menambah ilmu pengetahuan. ${ }^{9}$ Dengan kata lain metode penelitian dapat dikatakan sebagai proses prinsip-prinsip dan tata cara untuk memecahkan masalah-masalah yang dihapi didalam melakukan penelitian.

Peneliti hukumanya pada hakekatnya merupakan suatu kegiatan ilimiah dimana didasarnya pada motode, sistemateka, dan pikiran tertentu, dan bertujuan untuk mempelajari satu/ beberapa gejala hukum tertentu dengan jalanan menganalisisn, serta dadakan pemeriksaan yang mendalami terhadap fakta hukumnya tersebut untuk kemudian diusahakan suatu memecah atas pmasalah yang munsul atas tanda yang diteliti. ${ }^{10}$

Dalam penelitian hukum dikenal dua macam metode penelitian, yaitu metode penelitian hukum normatif dan metode penelitian hukum empiris.

\section{Tipe Penelitian}

Dalam penelitian ini metode yang digunakan oleh penulis adalah metode penelitian hukum yuridis normatif. Menurut Soerjono Soekanto penelitian yuridis normatif adalah penelitian hukum yang dilakukan dengan cara meneliti bahan pustaka atau data sekunder sebagai bahan dasar untuk diteliti dengan cara mengadakan penulusuran terhadap peraturan-peraturan dan literature yang berkaitan dengan permasalahan yang diteliti. ${ }^{11}$

\footnotetext{
9) Soerjoeno Soekanto, pengantar penelitian hukum, (Jakarta: UI Press, 1986), hal. 6.

10) Sorjoeno Soekanto, pengantari penelitian hukum, (Jakarta: UI Press, 2000), hal. 45.

11) Sorjono Soekanto da Sri Mamudji, penelitianya hukum normatif : suatu tinjauan singkat, (Jakarta: Rajawali Pers,2001), hal.13-14.
} 
Tipe penelitian normatif merupakan penelitian terhadap bahan pustakaa atau data sekunder mungkin mencakup bagan primer, sekunder, dan tersier. ${ }^{12} \mathrm{Di}$ dalam penelitian hukum terdapat beberapa pendekatan yang digunakan. Pendekatan-pendekatan yang digunakan di dalam penelitian hukum ini adalah sebagai berikut: ${ }^{13)}$

a) Pendekatan undang-undang (statue approach);

b) Pendekatan kasus (case approach);

c) Pendekatan historis (historical approach);

d) Pendekatan komparatif (comparative approach); dan

e) Pendekatan konseptual (conseptual approach).

Metode pedekatan yang penulis digunakan dalamini penulisan adalah pendekatan undang-undang (statue approach) dan pendekatan kasus (case approach). Pendekatan undang-undang disini adalah dilakukan dengan cara menelaah undang-undang yang berkaitan dengan isu yang dihadapi dan dengan pendekatan kasus yang dilakukan dengan cara telaah terhadap kasus yang berkaitan dengan isu yang dihadapi, yang telah menjadi putusan pengadilan yang mempunyai kekuatan hukum tetap. ${ }^{14)}$

\section{Sifat Penelitian}

Sifat Penelitian yang dipergunakan dalam penelitian ini adalah metode deskriptif analitis. Metode deskriptif analitis dipergunakan untuk memberikan gambaran tentang isu hukum atau pokok permasalahan yang akan diteliti. Penelitian hukum ini didukung dengan data wawancara.

\section{Teknik Pengumpulan Data}

Di dalam penelitian Hukum, jenis mengumpulkan berkas, yaitu setudi dokomen ataupun bahan pustakaan, pemerhatian atau obserfasi, dan wawancana atau interfiew. tiga jeniis alat pengumpulan data tersebut bisa

${ }^{12)}$ Soerjono Soekanto, pengantar penelitian hukum, (Jakarta: UI Press, 1986), hal.52.

13) Peter Mahmud Marzuki, Penelitian Hukum, Cetakan ke-8, Edisi Revisi, (Jakarta: Kencana, 2013), hal.181.

14) ibid., hal. 134. 
digunakan masing-masing maupun secara bergabung untuk mendapatkan hasil yang semaksimal mungkin. ${ }^{15)}$

Teknik pengumpulan data yang digunakan adalah melalui studi dokumen atau bahan pustaka (library research), yaitu dalam penyusunan skripsi ini penulis menggunakan content analysis yaitu setiap teknik untuk membuat inferensi secara objektif dan sistematis untuk mengidentifikasi karakteristik pesan yang spesifik terhadap berbagai buku, catatan, dan sebagainya yang relavan atau berkaitan dengan penelitian yang sedang diteliti.

4. Jenis Data dan Bahaan Hukumnya

Bahan-Bahan hukum dialam penelitian ini meliputi 3 (tiga) kelompok, yaitu bahan hukum priimer, bahan hukum sekunderr serta bahan hukum tersiier.

a) Bahanan hukum premier merupakan bagian hukum yang sifati autortatif artiinya punya otoritasi, yaitu :

- Undang-undang Nomor 5 Tahun 1960 tentang Peraturan Dasar Pokokpokok Agrariia;

- Undang-undang Nomor 3 Tahun 1997 tentang Ketentuan Pelaksanaan Peraturan Pemerintah Nomor 24 Tahun 1997 tentang Pendaftaran Tanah;

- Kitab Undang-Undang Hukum Perdata;

- Putusan Pengadilan Tinggi Jawa Barat (nomor 571/Pdt/2017/PT.BDG.)

b) Bahan hukum sekunder, merupakan bahan hukum yang memerlukan penjelasan lebih luas mengenai bahan hukum primer yang bukan merupakan dokumen resmi seperti buku, artikel, jurnal, dan internet yang berhubung dengan penyelidikan ini.

\section{hal. 66 .}

${ }^{15)}$ Sorjono Soekanto, Pengantar Penelitian Hukum, Cetakan ke-3, (Jakarta: UI Press, 2006), 
c) Bahan hukum tersier, yaitu bahan hukum yang menyokong bahan hukum primer dan sekunder serta dapat berikan arahan di antara keduanya. Bahan hukum tersier yang digunakan adalah kamus bahasa Indonesia.

d) Bahan Non- hukum yaitu bahan-bahan pendukung dari luar bahan hukum primer maupun sekunder sebagai bahan pelengkap bukan yang utama serta memberikan petunjuk tambahan terhadap bahan-bahan hukum tersebut yaitu berupa Kamus Besar Bahasa Indonesia (KBBI), dan wawancara dengan narasumber (Ahli hukum) sebagai upaya mendapatkan pendapat hukum tentang objek yang diteliti.

\section{Teknik Analisis Data}

Analisis data yang digunakan yaiti analisis kualitatif, yaitu menguraikan dan menginterprestasikan data dalam bentuk kalimat yang baik dan benar untuk memperoleh jawaban singkat yang dirumuskan secara deduktif. Berdasarkan analisis data kualitatif, maka hasil penelitian ini akan diuraikan dalam bentuk kalimat yang disusun secara sistematis, jelas, dan rinci sehingga dapat diinterprestasikan untuk memperoleh suatu kesimpulan secara deduktif untuk menjawab pokok bahasan yang ada.

\section{PEMBAHASAN}

\section{A. Akibat Hukum Pembatalan Akta Perjanjian Pengikatan Jual Beli (PPJB) Yang dilakukan Oleh Debitur Tanpa Memenuhi Prestasi dalam Perjanjian.}

Dalami hidup komuniti manusia menpunyai kebutuhan hidup sangat berbeda-beda, dimana untuk pemenuhan keperluan hidup itu dilakukan dengan bekerjasama dengan manusia atau masyarakat yang lain, dimana manusia tidak dapat memenuhi kebutuhannya tanpa bantuan akau kerja sama dengan orang laiin. Dalami menjalinya suatu hubungan maupun kerja sama khususnya dibidang bisnis, dang terpenting adalah kata kesepakat diantaranya dua pihak. Kata kunci sepakat sangat penting untuk kedua para pihak karena kesepakatan 
tersebut mempunyai manfaat bersama untuk pihak yang membuat tersebut. Suatu kesepakatan itu akan mengikat kedua belah pihak yang membuatnya dalam suatu perjanjian. Kitab Undang-Undang hukumnya perdata dikenal bagai perijanjian contohnya dari perjanjian yang selalunya temui dalam kegiatan sehari-hari adalah perjanjian jual beli. Agar bisa mengadakan jual belih tanah oleh para pihak sepakat menjual beli tanah bisa dijalankan apabila seetelah sertifikat telah di urus, atau harga yang dijanjikan sudah dilunasi sesuai dengan kesepakatan yang disepakati bersama. Untuk menjaga agar kesepakatan itu tetap terlaksana dengan baik sementara persyaratan yang diminta bisa tetap dapat di urus, maka biasanya para pihak yang akan melakukan transaksi jual beli tanah menuangkan kesepakatan awal tersebut dalam bentuk perjanjian yang kemudian dikenal dengan perjanjian pengikatan jual beli. Akta Perjanjian Pengikatan Jual Beli dalam Notaris sering disebut atau dikenal dengan Akta Pengikatan Jual Beli (PPJB). Dilakukannya suatu perjanjian pengikatan jual beli (PPJB) karena akan terjadinya suatu proses penjualan tanah, dimana pembeli dan penjual membuat pemindahan hak tanah dengan berdasarkan perjanjian yang dinyatakan dalami perjanjian jual beli dimana peralihan haki tanah tersebut wajib dilaksanakan didepan penjabat umum yang berewenang. Untuk dapati melakukan suatu perjanjian maka para pihak harus memenuhi beberapa syarat sahnya suatu perjanjian yang telah diatur atau ditentukan dalam Pasal 1320 KUHPerdata yaitu : sepakat mereka yang mengikat dirinya, kecakapan untuk membuat suatu perjanjian, suatu hal tertentu, dan suatu sebab yang halal. Para pihak penjual dan pembeli yang menyepakati perjanjian tersebut menghendaki suatu kepastian hukum. Suatu kepastian hukum itu dapat diperoleh dari perjanjian tertulis yang dibuat oleh pejabat yang berwenang. Salah satu pejabat yang berwenang untuk membuat perjanjian tertulis yang dapat digunakan sebagai alat bukti di kemudian hari adalah Notaris. Akta pengikatan jual beli yang telah dibuat oleh notaris pada awalnya tidak ada masalah, akan tetapi dalam pelaksanaannya seringkali terjadi permasalahan, 
permasalahan itu timbul ketika salah satu pihak merasa dirinya dirugikan oleh pihak lainnya dimana PPJB tersebut tidak dilaksanakan sesuai dengan kesepakatan bersama. Permasalahan tersebut pada akhirnya menimbulkan suatu sengketa, dimana salah satu pihak menghendaki pembatalan atas akta pengikatan jual beli (PPJB) yang telah dibuat sebelum ini. Dikarenakan kelalaian yang dilakukan oleh Jhoni Hendra (Tergugat) dimana tergugat tidak melaksanakan kewajibannya maka hal tersebut telah menimbulkan kerugian untuk Suhada,S.E (Penggugat).

Akta Pengikatan Jual beli diadakan oleh kedua belah pihak yang hadir di hadapan notaris untuk membuat PPJB. Gustiah Rahmawati S.H., M.Kn., selaku notaris menjelaskan bahwa pada saat para pihak menandatangani Pengikatan Jual Beli No.10 di hadapan Notaris tidak ada pembayaran, namun hanya ada kata sepakat untuk membayar tanah Suhada,S.E., secara mencicil atau bertahap oleh Jhoni Hendra sesuai dengan perjanjian yang telaah di sepakati dalam PPJB No. 10. Karena belum adanya pembayaran maka kedua belah pihak sepakat untuk membuat akta pengikatan perjanjian jual beli terlebih dahulu, nanti apabila pembayaran yang telah diperjanjikan oleh Jhoni Hendra sudah lunas maka Pengikatan Jual Beli ini akan ditingkatkan menjadi Akta Jual Beli (AJB). PPJB tersebut dibuat dihadapan notaris pada hari Jumat tanggal 21 November 2014 dimana objek yang diperjualbelikan adalah tanah milik Suhada kepada Jhoni Hendra dengan total luas 12.981 M2 di kec. Limo Kota Depok dengan jumlah harga sebesar Rp. 8.437.650.000,- (delapan milyar empat ratus tiga puluh tujuh juta enam ratus lima puluh ribu). Dalam PPJB tersebut terdapat ketentuan yang harus dipenuhi atau dibayar oleh jhoni hendra, dalam perjanjian tersebut terdapat termin pembayaran yang harus dicicil oleh Jhoni Hendra tahapan pembayaran dilakukan dari 21 November 2014 sampai dengan bulan Desember 2016. Ternyata sampai tanggal 21 Agustus tergugat baru membayar sebesar Rp. 650.000.000,- dimana tidak sesuai dengan masa pembayaran tanah dalam PPJB No.10 yang penggugat dan tergugat telah sepakati bersama, dan 
penggugat telah melakukan teguran-teguran lisan, melalui telepon, surat pemberitahuan, surat peringatan maupun menemui langsung tergugat untuk segera membayar sesuai termin pembayaran yang telah disepakati terhadap penggugat, akan tetapi tergugat belum juga melakukan pembayaran yang seharusnya dilakukan oleh sebab itu penggugat mengajukan gugatan ke pengadilan Depok untuk membatalkan akta PPJB No.10 yang telah diterbitkan oleh Notaris Gustiah Rahmawati S.H., M.Kn. Majelis Hakim menilai dan menimbang bahwa tergugat telah memenuhi kriteria wanprestasi yaitu: melaksanakan tetapi tidak seperti yang diperjanjikan, dimana tergugat memang benar telah melakukan pembayaran pembelian Tanah namun tidak seperti yang diperjanjikan dimana saat diberikan surat peringatan, menunjuk bukti bahwa tergugat baru membayar senilai Rp.650.000.000 (enam ratus lima puluh juta rupiah) dari setidaknya Rp.2.000.000.000,- (dua milyar rupiah) yang seharusnya telah dibayarkan oleh tergugat. Dengan dinyatakan terdapat suatu wanprestasi maka konsekuensi hukumnya adalah dapat dimintakan pembatalan terhadap perjanjian yang berkaitan dengan wanprestasi tersebut.

Perjanjian Pengikatan Jual Beli (PPJB) dalam prakteknya dimungkinkan untuk dibatalkan secara sepihak oleh salah satu pihak atau atas kesepakatan kedua belah pihak. Perjanjian Pengikatan Jual Beli (PPJB) tersebut dapat pula dibatalkan oleh suatu keputusan pengadilan. Dibatalkannya suatu akta perjanjian yang dibuat secara otentik tentu akan membawa konsekuensi hukum. Bila dilihatt dari kewajiban pembelia, maka dialam jual beli ini pembeli juga mempunyaii tugas yang pertama. Obligasi utaman yang harus dipenuhi oleh pihak itu sendiri adalah membayar harga dari obyek penjualan yang diperjualbelikan mengikuti harga yang dipersetujui. Bilamana pembeli tidak membayar pembayaran sesuai dengan kesepakatan maka penjual boleh menuntut pembatalan penjualan tanah tersebut. 
Pasal 1320 KUHAPerdata maturan bahwa untuk suatu perjanjiian sah perlukan empati syarat wajib harus dipenuhi, lainnya pesyaratan yang terkandung didalam Pasal 1320 KUHPerdata tersebut juga masiih ada yang diperlukan lainny, menurut hukum adat untuk keabsahan suatu perjanjian peralihan haki tanah. Persyaratan penjualan dan belii menurutnya hukum adat tersebutt itu: (a) "Tunai" dan (b) "Terang". Secara ringkas "tunai" bermakna bahwa laksanaan jual beli dan pemindahan hakk tanah dari penjual ke pembeli ditanggap telah berlaku disaat pihak tersebut menyatakan kesepakaatan dalam perjanjian. Meski jual beli itu pembayaran bukan dengan "tunai" dalam pengertian setiap hari, hal tersebuti bukanlah merupakan suatu prinsipal dan dianggapi bagai suatu penghutang utang diantara penjual dan pembeli. Selanjutnya "terang" artiya bahwah pelaksanaan jual beli hak utuk tanah mesti dibuat sebelum pegawai yang diberi kuasa dan dihadirkan oleh saksimata. Dalam Pasal 1266 KUHPerdata menjelaskan atau menerangkan bahwa wanprestasi secara senantiasa dianggapi bagaii syarat batal dalami suatu perjanjiannya supaya pihak yang rasanya dirugikan oleh pihak lain yang melakukan ingkarjanji, bisa melakukan pembatalan perjanjian melewati pengadilani, baik dikarena keingkaran tersebut dinyatakan sebagai kondisi batal didalam perjanjian atau tidak ada di perjanjian, jika kondisi dibatalkan tidak dimasukkan dalam janjian itu, hakim dapat memberikan kesempatan kepada pihak yang ingkar janji agar terus memenuhi perjanjian dan memberi tempo waktu yang tidak melebihi satui bulannya. Dari hasil penelitian ada beberapa alasan atau faktor-faktor yang dapat mengakibatkan terjadinya pembatalan akta perikatan jual beli tersebut, yaitu:

a. Ada klausula-klausula di dalam perjanjian menyatakan batal demi hukum;

b. Tidaknya memenuhian syarat pembuatan di ditentukan oleh undang-undang; 
c. Tiada suatu kesanggupan para pihak untuk melaksanakan suatu perikatan tersebut;

d. Harga jual beli yang telah disetujui dalam perjanjian perikatan jual beli belum dilunasi oleh pihak pembeli sehingga tempo masa waktu yang telah dipersetujui (ingkar janji);

e. Surat-surat tanah yang dibutuhkan untuk pemindahan hak atas tanah itu (jual beli tanah dihadapan PPAT) belum selesai sampai jarak waktu yang dijanjikan;

f. Benda jual beli nyatanya dikemudian hari ada dalam keadaan atau peristiwa sengketa;

g. Para pihak tidak melakukan kewajibannya dalam membayar pajak;

h. Perjanjian beli tanah itu diputusnya oleh para pihak yang membuatnya;

i. Putusan pengadilan.

Kemudian berdasarkan permasalahan diatas menurut pandangan Ibu Tjempaka, ia menjelaskan bahwa permintaan pengganti kerugian dapat atas prestasi pokok, juga dapat pula pengganti kerugian tambahan sekaligus. Pengganti kerugian prestasi pokok dikarena debitur tidaklah memenuhinya prestasi sama sekali, sedangkan pengganti kerugian tambahan karena debitur terlambat pemenuhan prestasinya. Kemudian Akibat hukum dari PPJB yang sudah diperbuat oleh para pihak maka para pihak harus patuh dengan apa yang sudah dicantumkan atau ditulis dalam isi akta PPJB tersebut. Berlaku Pasal 1338 KUHPdt. Apabila salah satu pihak merasa kurang bernasib baik karena perbuatan oleh pihak yang satunya telah melakukan wanprestasi atau melakukan perbuatan melawan hukum oleh pihak yang merasa dirugikan tersebut dapat mengajukan perkaranya di pengadilan tempatan. PPJB yang dibuat isinya haknya dan kewajibanya para pihak. Karena PPJB yangi mereka buat memiliki kekuatani hukum sangat sempurna untuk pihak yang membuatnya karena dalamnya pembuatan PPJB tersebut dibuat dengan 
mengikuti teori perikatan yang diatur dalam KUHPdt secara otomatis para pihak terlindungi dari akta yang telah mereka buat.

Kemudian penulis juga mewawancarai Bapak Hanafi Tanawijaya S.H., M.H., dosen Universitas Tarumanagara yang berpendapat bahwa, pembatalan PPJB itu jika klausul-klausul yang sudah ada atau dibuat para pihak itu tidak dipenuhi. Contohnya waktu pembayaran pihak pembeli harus membayar tetapi pihak pembeli itu tidak menepati janjinya sehingga itu bisa menjadi salah satu syarat PPJB itu dapat dibatalkan. Perjanjian pengikatan jual beli (PPJB) dapat juga dibatalkan dari pihak penjual dalam suatu hal tertentu dapat membatalkan PPJB itu tetapi dengan suatu konsekuensi misalnya dia (penjual) tidak jadi menjual barangnya dengan alasan-alasan tertentu, jadi perjanjian itu dapat dibatalkan tetapi apa yang sudah diberikan oleh pembeli harus dikembalikan kembali oleh penjual. Secara umum perjanjian itu hanya dapat dibatalkan atas kesepakatan bersama tidak bisa suatu perjanjian dibatalkan secara sepihak, sehingga perjanjian itu dapat dibatalkan atas kesepakatan para pihak yang membuat perjanjian tersebut. Faktor-faktor yang dapat membatalkan suatu perjanjian, yaitu wanprestasi dan terdapat alasan kenapa bisa terjadi wanprestasi contohnya force mejuere (keadaan memaksa) dan ada sesuatu yang dianggap luar biasa.

Pada bab ini penulis akan menganalisis permasalahan terkait akibat hukum pembatalan perjanjian pengikatan jual beli. Menurut peruntukan Pasall 1266 ayat (1) KUHPeridata sebab batal dicantumkan dalami perjanjian, apabila dari salah satunya pihak dalaim perjanjian mengingkari apapun yang telah diperjanjikanya. Pasal 1266 ayat (2) menerangkan suatu perjanjian dapat dibatalkan wajib dengannya pemutusan hakim. Pasal 1266 ayat (3) menegakkan bahwa meminta pembatalan perjanjian bisa dilakukani, meskip sebab batal telaah dinyatakan diaalam perjanjian. Sebagaimana telah dijelaskan diatas dalam Pasal 1320 apabila syarat subyektif tidak dipenuhi mengakibatkan perjanjian tersebut dapat dibatalkan. Untuk meminta 
dilakukannya suatu pembatalan dalam perjanjian itu dapat dilakukan dengan cara yaitu:

a. debitur yang mempunyai kepentingan secara aktiif menggugat ataupun dapat memintakan kepada majelis hakim agar janjianya ini dapat dibatalkan.

b. tunggu sampai datangnya gugatanya didepan hakim untuk pemenuhin perjanjiannya.

batalannya suatu perjanjian yang dilakukan dli hadapan pengadilan diseabkan pada siaat janji itu sedang terjadi, dimana salah pihak yang satu tidak cakapi untuk lakukan suatu perlakuan hukum, perjanjian itu disetujui karena pihak tersebut berada dibawah kecaman atau karenaya khilafan mengenai objeknya perjanjian. Karena itu pihak yang dirugi dapatnya meminta kepada hakim agar perjanjian itu agsr dapat di batalkan. Secara umum pembatalan suatu perjanjian dapat dikelompokkan sebagai berikut :

1. Terdapat kemungkinan peraturan yang mengatur hal pembatalanya kontrak yang diaturi dalam suatu perjanjian,

a. Disebutkannya suatu sebab pemutusan perjanjian

Di suatu perjanjian seringkali disebutkan alasan-alasan hingga salah satunya pihak dapat membatalkan perjanjian, biasanya wanprestasi tetapi tidak semua wanprestasi dapat menyebabkan putusnya suatu perjanjian, hanya beberapa wanprestasi saja yang disebut ada di perjanjian.

b. Perjanjian bisa dibatalkan oleh kesepakatan dua bela pihak

c. Penyimpangan pada Pasal 1266 KUHPerdata

Dimana para pihak dalam pemutusan perjanjian tidak perlu ditempuh lewat pengadilan tetapi diputuskan langsung oleh para pihak yang membuatnya. Dapat dilihat bahwa pasal 1266 KUHPerdata sering dikesampingkan, karena pasal tersebut setiap ingin melakukan pemutusannya perjanjian harus dilakukaan lewati jalur pengadilan. 
d. Tatanan caranya pembatalan perjanjiannya

Di samping pembatalan perjanjian belum dilakukan lewat pengadilan biasanya pembatalan tersebut ditentukan sendiri oleh para pihak yang membuat perjanjian tersebut . Biasanya pihak yang ingin melakukan pembatalan perjanjian harus terlebih dahulu memberi peringatan kepada pihak yang tidak memenuhi prestasinya untuk melakukan kewajibannya, pemberitahuan dilakukan dua atau tiga kali. Bila peringatan tersebut tidak diindahkan oleh tergugat maka pihak pihak yang dirugikan tersebut dapat langsung memutuskan perjanjian tersebut. Memberi Peringatan ini sejalan dengan prinsip KUHPerdata yaitu di keluarkannya "akta lalai" oleh para pihak kreditur atau penggugat (Pasal 1338 KUHPerdata), dimana somasii (sebuah teguran) pada dasarnya sangat perlu agar dapat memutuskan suatu kontrak.

2. Pembatalannya suatu janjian dikarena wanprestasi

bila terjadi wanprestasi dalam suatu perjanjian, daripada pihak lain diberi beberapa hak yaitu :

a. Pengecualian dan bukan adimpletai contractius, pihak yang dirugikanya dikarenakan kejadian ingkarjanji boleh ditolak untuk prestasai untuk lanjut.

b. Menolak suatu prestasi oleh pihak lawannya

c. Meminta resititusi, pihak yang telah melakukan prestasi berhak menuntut agar dapat dibayar kembali segala prestasi dan sudah dikerjakan.

3. Pembatasannya di dalam pembatalan perjanjian

Seperti yang sudah diterangkan bika salah satunya pihak mengerjakan wanprestasi maka pihak yang dirugikan akibat wanprestasi tersbut berhak memutuskan perjanjian yang bersangkutan. Tetapi pihak-pihak yang rugi dari wanprestasi dapat diberlakukan restribusi yuridis yaitu : 
a. (Wanprestasi yang disengaja), Tidak semua pihak yang dirugikan karena wanprestasi dapat membatalkan perjanjian. dilainkan pihak yang merugikan harus dapat membuktikan bahwa wanprestasii itu merupakan wanprestais yang disengaja oleh pihak lain yang melakukannya.

b. (Hak untuk membatalkan perjanjian belum dikesampingkan), di teoritis hukum perjanjian hak untukn dapat berbuat pembatalan perjaanjian dikarena pihak lain setelah mengerjakan wanprestasi tetapi tidaklah berlaku lagi apabila pihak yang merugik sudaah mengenyampingkan kepentingannya untuk membatalkan perjanjian itu.

c. (Pembatalan suatu janjian tidaklah boleh terlambat), pembatalan suatu janji darii pihak yang merugikan karenanya wanprestasi pihak lainya harus dilakukan dalam paruh jam yang cukup (waktu yang jelas). Hal ini diperuntukkan untuk mengasih kepastian hukum kepada pihak yang wanprestasi untuk melanjutkan atau tidak wanprestasi yang belum sempat terselesaikan.

d. (Wanprestasi yang disertai dengan unsur yang mengandung salah), dalam KUHPerdata tidak memsyaratkan adanya dasar kesalahan agar dalam perjanjiann bisa dibatalkan bagi pihak yang dirugikan atau agar dapat dituntut atas suatu pembayaran ganti rugi. Berdasarkan Pasal 1266 KUHPerdata melibatkan pengadilan dalam memutuskan perjanjian timbal balik, maka penggunaan keputusan atau tindakan pengadilan untuk membatalkan perjanjian itu juga menggunakan faktor kesalahan pihak yang melakukan ingkarjanji untuk dapat menentukan apakah perjanjian tersebut dapat diputuskan atau tidak oleh pengadilan.

Seperti itu, apabila pada dasarnya apabila ada suatu kewajipan yang tidak dikerjakan dan juga kewajiban yang tidak dilakksanakan dan dimana suatu 
perbuatan tersebut menimbulkan kerugian, maka perjanjian tersebut dapat diputuskan dang anti rugi dapat dimintakan. Asal kewajiban yang tidak dilaksanakan hal itu bukan dikarena hal-hal yang bersifatnya forcee majeure (keadaan memaksa), hal tersebut tidak diatur oleh hukum yang mengatur tentang wanprestasi tetapi sudah merupakan ranah hukum yang lain, yaitu hukum yang mengatur tentang force majeure (keadaan memaksa) dan resiko.

B. Bagaimana Pertimbangan Hukum yang digunakan oleh Hakim dalam Mengambilan pemutusan atas Pembatalanya Akta Perjanjian Pengikatan Jual Beli (PPJB) dalami Putusan Pengadilan Tinggi Jawa Barat No 571/PDT/2017/PT.BDG.

Sebelum pembuatan akta jual beli tanah yang dibuat oleh dan dihadapan PPAT yang berwenang terlebih dahulu para pihak membuat suatu perikatan jual beli yang berisi janji-janji para pihak untuk mengerjakan surat ikatan hukum yaitu jualdan membeli tanah. Perikatan tersebut dibuat dalam bentuk akta notaris yang muncul sebagai suatu kebutuhan hukum dari masyarakat. Surat PPJB tanah yang dibuatin hadapan notaris berupakan akta otientik yang punyai kekuatan pembuktian yang sempurnaa, maknanya apabila salah satu pihak mengalami kerugian maka hakim harus menerima dan menganggap apa yang dituliskan dalam akta itu sungguh telah terjadi, sehingga hakim tidak boleh memerintahkan penambahan pembuktian lagi, hal ini juga dimaksudkan kepada para pihak agar lebiih dapat memberikan bentuk perlindungan dan kepastian hukum kepada para pihak yang membuatnya, karena didalam suatu perjanjian belum dapat selamanya jalann disesuai dengan sepakatnya yang dinginikan dari para pihak yang membuatinya terdapat keadaan yang berakibat suatu perjanjian harus berakhir karena tidak sesuai dengan kesepakatan awali. Berdasarkan Pemutusan Pengadilan Negeri Depok Nomor: 164/PDT.G/2015/PN.Dpk. dan Putusan Pengadilan Tinggi Bandung Nomor : 571/PDT/2017/PT.BDG ditemukan beberapa alasan dan 
dasar pertimbangan hukum yang digunakan hakim dalam pengambilan keputusannya sehingga dibatalkannya akta perjanjian perikatan jual beli tanah yang telah dibuat sebagai berikut :

a) Tergugat telah melakukan wanprestasi dengan belum melunasi pembayaran hargai tanah sesuai dengan paruh waktu yang telah diperjanjikan Isi Perjanjian pengikatan jual beli (PPJB) berupa janji-janji, hak dan kewajiban paraipihak yang mengandung ketentuanan tentang syaratsyaratnya yang disepakat untuknya sah melakukan suatu perjanjian. Perjanjian disebut bersifatnya mengikati hingga mentimbulkan hak dan kewajibani dari para pihak yang membuatnya apabila jika salah satu pihak melanggar apa yang telah dijanjikan dan menimbulkan bahaya bagi pihaki lainnya maka pihak yang merasa dirugikan dapat mengajukan gugatan kepadanya. Kutipan pertimbangan hakim sebagaimana dibawah ini: Menimbang, bahwa sebagaimana telah menjadi dalil tetap sebagaimana diuraikan di atas yang pada intinya telah terjadi perbuatan hukum perjanjian jual beli tanah antara penggugat dan tergugat yang tertuang dalam akta PPJB No.10 dimana tergugat berkewajiban untuk membayarkan harga tanah seluruhnya sebesar Rp. 8.437.650.000,- (delapan milyar empat ratus tiga puluh tujuh juta enam ratus lima puluh ribu) namun tergugat baru membayar sebesar Rp.650.000.000 (enam ratus lima puluh juta rupiah) maka majelis hakim menilai bahwa pada intinya tergugat belum memenuhi kewajibannya untuk melakukan pembayaran terhadap pembelian tanah sebagaimana telah ditentukan dan disepakati di dalam perjanjian oleh sebab itu tergugat telah memenuhi kriteria wanprestasi dimana tergugat melaksanakan prestasi tersebut tetapi tidak seperti yang diperjanjikan. Dan wanprestasi merupakan salah satu syarat agar dapat dibatalkannya suatu perjanjian pengikatan jual beli. Dan tergugat dapat di katakan wanprestasi juga didukung dari bukti-bukti yang di serahkan saat di dalam persidangan 
yaitu bukti surat peringatan yang diberikan oleh penggugat, yaitu fotocopy surat peringatan I fotocopy rencana realisasi pembayaran pembelian tanah. Majelis hakim berpendapat bahwa pada intinya tergugat mengakui bahwa memang tergugat belum memenuhi kewajibannya untuk melakukan pembayaran terhadap pembelian tanah sebagaimana telah ditentukan dan disepakati di dalam perjanjian perikatan jual beli nomor 10. Dan majelis hakim juga menimbang dari keterangan saksi-saksi baik dari pihak penggugat maupun pihak tergugat yang pada intinya menerangkan bahwa tergugat belum memenuhi kewajibannya untuk membayar secara keseluruhan berdasarkan termin pembayaran yang tercantum dan disepakati di dalam PPJB.

b) Tindakan Wanprestasi yang menyebabkan pembatalan perjanjian perikatan jual beli tanah

Bentuk -bentuk wanprestasi yang memunkinkan terjadi dialami perjanjian pengiikatan jual beli:

1. Pembeli menunda-nunda pembayaran isspiharga tanah yang seharusnya

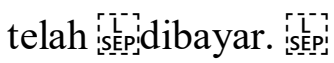

2. Pembelian melakukanya pembayaran tetapi iș ispitidak sebagaimananya yang dipejanjikan.

3. Pembelii belum membayari denda atas keterlambatanaya membayar harga tanah ini atau terlambat membayar istepidenda itu.

Berdasarkan bentuk-bentuk ingkar janji yang telah dijelaskan diatas tindakan wanprestasi yang dilakukan tergugat yaitu tergugat melakukan pembayaran tetapi tidak sebagaimana yang diperjanjikan, dimana harga yang seharusnya dibayar oleh tergugat tetapi tergugat tidak juga membayar sesuai dengan apa yang diperjanjikan. Dan bahwa di dalam PPJB nomor 10 pada pasaal 3 berbunyi "bahwa bilamana sampai dengan saat atau masa yang dimaksudkan dalam pasal 2 ayat (a) sampai (d) diiatas pihak kedua 
(tergugat) tidak atau belum juga melakukan pembayaran maka pihak kedua (tergugat) dinyatakan lalai, kelalaian tersebut cukup dibuktikan dengan lewatnya waktu pembayaran saja tanpa diperlukan surat teguran dari jurusita ataupun surat lainnya dan atas kelalaian tergugat tersebut wajib membayar denda.

maka dapat dikaitkan dengan pertimbangan hakim yang menimbang, bahwa dengan telah dinyatakan oleh majelis hakim bahwa tergugat telah melakukan wanprestasi terhadap PPJB No.10 maka konsekuensi hukumnya dapat dimintakan pembatalan terhadap PPJB No.10 yang diterbitkan oleh Notaris Gustiah Rahmawati S.H., M.Kn. dan menyatakan PPJB tersebut cacat hukum dan tidak lagi mempunyai kekuatan hukum yang mengikat.

c) Tergugat tidak mempunyai itikad untuk menyelesaikan perjanjian Perjanjian pengikatan jual beli (PPJB) adalah janjian terlebih dahulu dimana bentuknya bebas dan isian dari pejanjian pengikatan jual beli ini biasanya berupa janji-janjinya dari para pihak yang mengandung tentang ketentuan dan syarat-syarat yang disepakati untuk sah nya mengerjakan perjanjian pokoknya. Dimana klausull perjanjiannya berisi janji-janji baik dari pihak penjuali (penggugat) dan pihak pembeli (tergugat) tentang memenuhin terhadap syarat-syarat agar perjanjian jual beli dapat dilakukan agar dapat ditanda tangani dihadapan pejabat umum yang berwenang. Dan bukti yang mendukung bahwa tergugat tidak mempunyai niatan baik dalam menyelesaikan perjanjian ini adalah dari keterangan saksi yang telah diajukan oleh penggugat dimana saksi dari penggugat yaitu Pak Hidayat mengatakan bahwa penggugat sudah 3 (tiga) kali menegur tergugat secara tertulis untuk membayar kekurangan pembayaran transaksi jual beli tanah tetapi tergugat tidak mengindahkan teguran dari penggugat, dan benar bahwa tidak ada itikad baik dari tergugat untuk melakukan pembayaran.

\section{PENUTUP}


Berdasarkan penjelasan dan pembahasan yang telah penulis uraikan dari bab-bab sebelumnya, maka penulis dapat menarik kesimpulan secara umum yaitu :

1. Perjanjian pengikatan jual beli tanah merupakan perjanjian yang muncul dari kebutuhan hukum yang tumbuh dan berkembang dalam masyarakat, pengikatan jual beli merupakan perjanjian tidak bernama karena tidak ditemukan dalam perjanjian yang diatur didalam KUHPerdata.

2. Faktorisasi umum yang sering muncul sehingga terjadina pembatalanya perjanjian pengikatan jual beli adalah ketiadaan niat baik dari pembeli yaitu sering terjadinya wanprestasi dimana pembeli tidak memenuhi isi janji yang sudah dibuat oleh para pihak, yaitu tidak tepat waktu dalam melunasi harga yang telah ditentukan dan diperjanjikan oleh para pihak. Dan wanprestasi tersebut merupakan syarat batal dalam suatu perjanjian.

3. Akibat hukum dalam pembatalann perjanjian pengikatan jual beli tanah adalah para pihak wajib memenuhi tugasnya lebih dahulu sesuai dengan apa yang telah dijanjikan, sehingga apabila tidak dipenuhi para pihak dapat mengajukan pembatalan dengan kesepakatan para pihak yang membuatnya.

4. Akibat hukum pembatalan perjanjian pengikatan jual beli yang telah diputuskan oleh hakim adalah perjanjian tersebut yang diterbitkan oleh notaris telah dibatalkan dan PPJB tersebut cacat hukum dan tidak lagi mempunyai kekuatan hukum yang mengikat serta pihak yang melakukan wanprestasi atau yang menimbulkan kerugian dihukum untuk membayar biaya perkara.

Dari penyimpulan di atas penulis akan memberikan nasihat yang diharapkan agar membantu pembaca yaitu :

1. Diharapkan bagi para pihak pembeli maupun pihak penjual dalam membuat suatu perjanjian diharapkan lebih berhati-hati lagi dalam pembuatan isi perjanjian tersebut dimana wajib dilihat terlebih dahulu apakah dalam janji-janji tersebut sudah terdapat klausula yang menerangkan atau mengawali tentang peristiwa 
pembatalan perjanjian dan sebab apa saja yang dapat membatalkan perjanjian, serta apa saja konsekuensinya bagi para pihak jika terjadi pembatalan.

2. Hendaknya para pihak yang membuat perjanjian pengikatan jual beli diharapkan dapat memahami isi perjanjian pengikatan jual beli yang dibuatnya serta memahami setiap klausul-klausul yang dicantumkan dalam perjanjian tersebut, sehingga apabila suatu saat terjadinya suatu sangketa atau perbedaan pendapat, permasalahan tersebut dapat diminimalisir dengan baik.

\section{DAFTAR PUSTAKA}

\section{A. Buku}

Amirul, Aisikin Zinal. Pengantaran metode penelitian hukumnya. (Jakarta: Raja Graifindo Persada, 2004).

Marzuki,Mahmud Peter. Pennelitian Hukum. (Jakarta: Kenicana Prenada Media Group, 2005).

Patrik,Purwahide. dasar-dasar hukum perikatan. (mandari maju, bandung, 1994).

Salim,H. Teknik Pembuatan Akta Perjanjian (tpa dua). (Jakarta: Rajawali Pers, 2017).

Soekanto,Soerjono. pengantar penelitian hukum. (Jakarta: UI Press, 1986). dan Sri Mamudji, penelitian hukum normatif : suatu tinjauan singkat. (Jakarta: Rajawali Pers, 2001).

Subekti. Pokok-pokok hukum perdata. (Jakarta: PT.Intermasa, 2003) . Hukum perjanjian. (Jakarta: Intermasa, 2005).

Supriadi. Etika dan tanggung jawab profesi hukum di Indonesia, (Jakarta: Sinar Gafika, 2006).

\section{B. Internet}

Anonim. "pahami arti ppjb-pjb dan ajb agar terhindar dari penipuan". www.cermati.com, 22 September 2018. 